Biology Unmoored 



\section{Biology Unmoored}

MELANESIAN REFLECTIONS ON

LIFE AND BIOTECHNOLOGY

Sandra Bamford

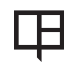

UNIVERSITY OF CALIFORNIA PRESS

BERKELY LOS ANGELES LONDON 
University of California Press, one of the most distinguished university presses in the United States, enriches lives around the world by advancing scholarship in the humanities, social sciences, and natural sciences. Its activities are supported by the UC Press Foundation and by philanthropic contributions from individuals and institutions. For more information, visit www.ucpress.edu.

University of California Press

Berkeley and Los Angeles, California

University of California Press, Ltd.

London, England

(C) 2007 by The Regents of the University of California

Library of Congress Cataloging-in-Publication Data

Bamford, Sandra C., 1962-

Biology unmoored : Melanesian reflections on life and biotechnology / Sandra Bamford.

p. $\mathrm{cm}$.

Includes bibliographical references and index. ISBN: 978-0-520-247I2-3 (cloth : alk. paper) ISBN: 978-0-520-24713-O (pbk. : alk. paper)

I. Hamtai (Papua New Guinean people)—Ethnobiology. 2. Hamtai (Papua New Guinean people)—Agriculture. 3. Hamtai (Papua New Guinean people)—Psychology. 4. Body, Human-Social aspects-Papua New Guinea-Gulf Province. 5. Indigenous peoplesEcology_Papua New Guinea-Gulf Province.

6. Ethnobiology_Papua New Guinea-Gulf Province.

7. Biotechnology. 8. Genetic engineering. 9. Gulf Province (Papua New Guinea)—Social life and customs. I. Title.

$$
\begin{aligned}
& \mathrm{DU}_{740.42 . \mathrm{B}_{34}}{ }^{2007} \\
& 305.89^{\prime} 912-\mathrm{dc22}
\end{aligned}
$$

2006009333

Manufactured in the United States of America

$$
\begin{aligned}
& \begin{array}{llllllllll}
\text { I6 } & \text { I5 } & \text { I4 } & \text { I3 } & \text { I2 } & \text { II } & \text { IO } & \text { O9 } & 08 & 07
\end{array} \\
& \begin{array}{llllllllll}
\text { IO } & 9 & 8 & 7 & 6 & 5 & 4 & 3 & 2 & \text { I }
\end{array}
\end{aligned}
$$

This book is printed on New Leaf EcoBook 50, a I0o\% recycled fiber of which $50 \%$ is de-inked post-consumer waste, processed chlorine-free. EcoBook 50 is acid-free and meets the minimum requirements of ANSI/ASTM D5634-OI (Permanence of Paper). 
To my father and mother. Whatever kinship may be, I could not have asked for better parents. 
